\title{
The Comparative Value Relevance of Donation and Advertising Expenditure Before and After the Global Financial Crisis in Korea
}

\author{
Gee Jung Kwon ${ }^{1}$ \\ ${ }^{1}$ Department of Business Administration and Accounting, Hanbat National University, Daejeon, Republic of \\ Korea \\ Correspondence: Gee Jung Kwon, Department of Business Administration and Accounting, Hanbat National \\ University, San 16-1, Duckmyoung-Dong, Yuseong-Gu, Daejeon 305-719, Republic of Korea. Tel: \\ 82-42-821-1337. E-mail: geejung@hanmail.net
}

Received: February 3, 2013 Accepted: March 11, 2013 Online Published: April 27, 2013

doi:10.5539/ass.v9n5p34

URL: http://dx.doi.org/10.5539/ass.v9n5p34

\begin{abstract}
This paper investigates the comparative value relevance of donation and advertising expenditures before and after the 2008 global financial crisis in listed Korean stock markets between 2004 and 2011. To test whether the value relevance of donation and advertising expenditures is associated with the 2008 global financial crisis, this paper first divides its sample into pre- and post-December 31, 2007, periods and then divides those into several subgroups to observe value relevance changes according to the characteristics and conditions of listed firms in the Korean stock markets.

This paper's empirical results offer important evidence concerning the comparative changes in the value relevance of advertising and donation expenditures. First, advertising and donation expenditures have positive value relevance before and after the global economic crisis and show a positive association with firm value in every subsample group divided according to firm characteristics.

Second, the results show significant time-period differences in the value relevance of donation and advertising expenditures before and after the global financial crisis. The results also show that value relevance changes according to the circumstance and contexts of the firms (e.g., KOSPI vs. KOSDAQ, large vs. small and medium, high technology vs. low technology).
\end{abstract}

Keywords: advertising expenditure, donation expenditure, global financial crisis (CFC), firm value, value relevance

\section{Introduction}

Myers (1977) and Ohlson (1995) assume firm value to be a function of measurable and immeasurable net assets. Measurable assets are usually published as tangible assets, and immeasurable assets, as intangible assets. For decades, many researchers have perceived the importance of intangible assets as a value-relevant factor, with most reporting the empirical results of studies on $R \& D$ investment.

Some of the early R\&D investment studies document the significant value relevance of R\&D investment. Later studies suggest, though, that R\&D activity indeed has a positive impact on firm value (Griliches \& Mairesse, 1984; Hirschey, 1982; Hirschey \& Weygandt, 1985; Bublitz \& Entredge, 1989; Chauvin \& Hirschey, 1993; Sougiannis, 1994; Lev \& Sougiannis, 1996; Hall, 1999; Choi \& Jung, 2001; Chung \& Cho, 2004; Luo, 2005; Ahn \& Kwon, 2006). These studies inspired many countries, including Korea, to change their R\&D investment practices from expensing to capitalizing.

However, many studies have been indifferent to other intangible assets such as donation and advertising expenditures. Advertising is the process of announcing merchandise, products, and corporate images to unspecified individuals to promote sales. Donation is the non-business activity of giving free gifts such as merchandise, products, and money to the needy for charitable purposes. Whether intended for business purposes or not, both expenditure types can enhance a firm's reputation.

Fombrun et al. (2000) and Sen and Bhattacharya (2001) show that donations have positive effects on financial performance dimensions such as sales. They also indicate that a firm's charitable activities can enhance the image of a firm's products and merchandise, thus enhancing its overall reputation and, ultimately, its value. 
Other studies, such as Keller and Lehmann (2003), demonstrate the value relevance of advertising expenditure through the mechanism of the brand value chain model. They assume that advertising promotes a brand's image, which affects customers' buying motivation and eventually leads to higher firm value. Many studies have thus documented the significant value relevance of donation and advertising expenditures but have not treated them as capitalized items in financial statements; most countries' accounting rules demand the expensing of donations and advertising. Thus, accounting and finance research must focus on the possibility of capitalization.

Amid the global financial crisis (GFC) triggered in 2007 (Ryan, 2008) by the U.S. subprime mortgage crisis, many countries suffered severe economic recessions and stock market failures. Asian countries had already experienced a financial crisis in 1997. After that Asian financial crisis (AFC), many studies reported that the AFC changed the value relevance of earnings components. For example, Johnson et al. (2000), Janice and John (2008), and Choi et al. (2010) suggest that the value relevance of accounting variables changed after the AFC. They argue that the AFC significantly reduced the information value of accounting variables, thus reducing accounting information's value relevance. This paper assumes that the GFC and AFC have had similar impacts and have thus produced similar value relevance changes.

Therefore, this paper compares the value relevance of donation and advertising expenditures before and after the 2007 global financial crisis in listed Korean stock markets between 2004 and 2011. To test whether the value relevance of donation and advertising expenditure is associated with the global financial crisis, this paper divides its sample into pre- and post-December 31,2007, periods and further divides those into several subgroups to observe how value relevance changed according to the characteristics and conditions of the firms. The study divides its sample into several subgroups (such as KOSPI vs. KOSDAQ, large vs. small and medium, and high vs. low technology) to test the characteristics of the value relevance and the market response to firms' donations.

The remainder of this study is structured as follows. Section 2 outlines the literature on the value relevance of donation and advertising expenditures. Section 3 develops the study of hypothesis and designs the empirical models. Section 4 analyzes the empirical results of the main tests. Finally, Section 5 summarizes this paper discusses the limitations of this study and proposes future research plans.

\section{Literature Review}

\subsection{The Cause and Effects of the Global Financial Crisis in Korea}

Since 2007, many countries (including Korea) have suffered economic recessions due to the GFC caused by U.S. subprime mortgage defaults. Korea had already experienced the AFC of 1997, consequent to which many studies documented value relevance changes in accounting variables (Graham et al., 2000; Swanson et al., 2003; Davis-Friday et al., 2006; Janice \& John, 2008).

For example, Davis-Friday et al. (2006), comparing the value relevance of accounting variables in Asian countries such as Korea, Indonesia, Thailand, and Malaysia, show that the value relevance changed except in Korea. By contrast, Ho et al. (2001) indicate that the value relevance decreased significantly in Korea by comparing the value relevance of net income and net assets before and after the AFC in listed Korean financial markets. They report that the value relevance of accounting variables decreased slightly after 1997. Several studies have investigated whether the value relevance of accounting variables has changed since GFC. For example, Choi and Choi (2010) report that the value relevance of accounting information increased significantly after the GFC in listed Korean stock markets.

Despite their different causes and processes, the AFC and GFC produce similar economic impacts. This paper thus assumes that the value relevance changes that occurred in accounting variables after the AFC happened after the GFC.

\subsection{Literature Review on the Value Relevance of Donation Expenditures}

The literature provides empirical evidence that the donation activities that proxy for corporate social responsibility (CSR) have a positive effect on a firm's financial performance (Waddock \& Graves 1997; McGuire, Sundgren \& Schneeweis, 1988; Fombrun et al., 2000; Sen \& Bhattacharya, 2001; Smith, 2003, Brown et al., 2006; Fisman et al., 2006; Lev et al., 2006; Yu \& Kim, 2006; Bae et al.,2008; Kim et al., 2008; Choi et al., 2009; Choi \& Lee, 2009; Choi et al., 2009; Kim \& Choi, 2011; Kim \& Kim, 2011; Shin et al., 2011).

For example, McGuire, Sundgren, and Schneeweis (1988) argue that firms usually perform charitable acts to gain a social reputation. Smith (2003) also reports that CSR may increase a firm's reputation and thus enhance firm value. Moreover, Fombrun et al. (2000) and Sen and Bhattacharya (2001) document that CSR is positively associated with a firm's financial performance. 
In the same vein, Choi et al. (2009), Choi and Lee (2009), Choi et al., (2009), Kim and Choi (2011), Kim and Kim (2011), and Shin et al. (2011) have examined whether donation expenditures proxying for corporate social responsibility have value relevance in listed Korean stock markets. They suggest that firms' donation activities enhance their reputation, thus promoting their value.

Other studies such as Yu and Kim (2006) have sought to determine the most important factor in deciding donation expenditure levels. Their empirical results indicate that debt ratio, liquidity, and financial performance have significant impacts on donation amounts. Kim et al. (2008) have examined whether corporate ownership structures are associated with CSR using donation expenditure as a proxy for CSR. Their results suggest that the percentage of majority shareholdings, firm scale, R\&D investment, and cash flows are significantly associated with donation expenditures.

These studies offer evidence that CSR activities have the power to enhance a firm's reputation (which is very important to businesses) and thus promote its value. As CSR activities usually take the form of donations, CSR activity levels can be quantified by consulting the donation expenditures noted on financial statements.

\subsection{Literature Review on the Value Relevance of Advertising Expenditure}

Comanor and Wilson investigated the value relevance of advertising expenditures in 1967 and offered empirical evidence that they are significantly associated with accounting earnings proxying for firm value. After this study appeared, many others investigated the value relevance of advertising expenditure on the assumption that advertising strengthens a firm's brand name and reputation, thus promoting the firm's intangible assets and value.

Studies on the value relevance of advertising expenditures have not produced conclusive empirical results. Some have reported that advertising expenditures have significant value relevance (Peles, 1971; Abdel-Khalik, 1975; Clarke, 1976; Hirschey \& Weygandt, 1985; Lee, 1994; White \& Miles, 1996; Cho \& Jung, 2001; Paek \& Jeon, 2004; Jung \& Cho, 2004; Cho \& Ryu, 2006; Lee \& Choi, 2007; Huh et al., 2007), whereas others do not (Picconi, 1977; Bulitz \& Ettredge, 1989; Hall, 1993; Choi, 1994; Chung \& Lee, 1996; Kwon \& Lee, 1999; Yook, 2003; Parke, 2005; Kim et al., 2006). For example, White and Miles (1996) show that advertising has long-lasting effects on firm value and thus argue that advertising expenditures should not be expensed but capitalized. Other studies have sought to confirm whether advertising has long-lasting value relevance effects. Abdel-khalik (1975) investigates the value relevance of advertising in various industries, showing that advertising provides long-lasting value relevance in the food, drug, and cosmetics industries but not in the tobacco, soap, and cleaning industries.

Chauvin and Hirschey (1993) also report that advertising expenditures positively affect value relevance and that this value relevance is greater for large firms than for small and medium firms.

Contrariwise, other studies find no value relevance for advertising expenditures. For example, Bubblitz and Ettredge (1989) and Hall (1993) show that R\&D investment has a long-lasting impact on firm value and that advertising expenditures have a value relevance of only one year. On that basis, they conclude that R\&D investments should be capitalized and that advertising should not.

\section{Hypothesis and Empirical Model}

Many studies have investigated the value relevance of intangible investments such as donations and advertising. Smith (2003) indicates that CSR may enhance firm reputation, which is usually linked to firm value. Miles (1996) argues that advertising expenditures should be capitalized by documenting advertising's multi-period value relevance. The 2007 GFC changed the value relevance of accounting variables in the world's listed stock markets (Choi \& Choi, 2010), but no study has yet connected these variables with economic conditions.

Therefore, this study intends to address the value relevance of intangible investments such as donations and advertising in the context of the changes the GFC has inflicted on global financial markets. This paper examines the changes in the value relevance of donations and advertising in listed Korean stock markets between 2004 and 2011, before and after the GFC, and compares the value relevance of donations and advertising expenditure before and after GFC. This paper divides its sample into several subgroups to investigate the value relevance change according to the characteristics and conditions of the companies. The study proposes the following hypotheses:

Hypothesis 1: The value relevance of donation expenditures before and after the GFC differs.

Hypothesis 1: The value relevance of advertising expenditures before and after the GFC differs. 
To test these hypotheses, this paper replicates the empirical models in Myers (1997) and Ohlson (1995). Myers (1977) divides a firm's value into measurable parts and immeasurable parts as in equation (a) below:

$$
V=V(A)+V(G)
$$

$V$ : firm value, $V(A)$ : Value measurable of net assets, $V(G)$ : Value of immeasurable net assets

where $V$ refers to a firm's value measured as the sum of $V(A)$ and $V(G)$. In equation (a), $V(A)$ is defined as the value of measurable net assets, and $V(G)$ is the value of immeasurable net assets. $V(G)$ is not recorded in financial statements because it cannot be calculated. $V(G)$ usually includes the intangible assets not published in the financial statement because of their immeasurable characteristics such as entertainment costs, donation expenditures, advertising expenditures, corporate reputation, brand name, and customer loyalty (Barth et al. 1998; Black, 1998). Moreover, since Myers (1997), many studies have argued that immeasurable net assets can promote corporate future earnings and operating cash flows (Benard 1994; Biddle et al. 1995; Ohlson 1995; Collins et al. 1997; Barth et al. 1998; Black 1998). This paper adapts Myers (1977) by adding immeasurable variables such as donations and advertising expenditures, as in equation (b):

$$
M V=a_{0}+a_{1} B V+a_{2} I M A
$$

$M V$ : Market value of equity, $B V$ : Book value of equity, $I M A$ : Proxies for immeasurable assets

where $M V$ refers to the market value of equity, calculated as the sum of $B V$ and $I M A . B V$ is defined as the book value of equity, and $I M A$ proxies for immeasurable assets. In equation (b), IMA includes the intangible assets not recognized in financial statements, such as donation and advertising expenditures (Barth et al. 1998; Black 1998) This paper converts the model in Ohlson (1995) into the three empirical models below by adding donation and advertising expenditures:

$$
\begin{aligned}
& M V_{i, t}=a_{0}+a_{1} B V_{i, t-1}+a_{2} N I D_{i, t}+a_{3} D O N_{i, t}+\varepsilon_{i, t} \\
& M V_{i, t}=a_{0}+a_{1} B V_{i, t-1}+a_{2} N I A_{i, t}+a_{3} A D_{i, t}+\varepsilon_{i, t} \\
& M V_{i, t}=a_{0}+a_{1} B V_{i, t-1}+a_{2} N I D A_{i, t}+a_{3} D O N_{i, t}+a_{4} A D_{i, t}+\varepsilon_{i, t}
\end{aligned}
$$

where $M V_{i, t}$ refers to the stock price at the end of fiscal year $t$, year $t$ is the event year, $B V_{i, t-1}$ is the book value of the equity at the end of year $\mathrm{t}-1, N I D_{i, t}$ are the accounting earnings before deducting donation expenditures in period $\mathrm{t}, D O N_{i, t}$ is defined as the donation expenditure in period $\mathrm{t}, N I A_{i, t}$ are the accounting earnings before deducting advertising expenses in year $\mathrm{t}, A D_{i, t}$ is the advertising expenditure in period $\mathrm{t}$, $N I D A_{i, t}$ are the accounting earnings before deducting donation and advertising expenditures in year $\mathrm{t}$, and $\varepsilon_{i, t}$ is an error term in all equations. All variables are standardized by dividing the total numbers of shares outstanding at the end of fiscal year t.

To analyze these empirical models, this study splits its sample into several subgroups (KOSPI vs. KOSDAQ, large vs. small and medium, and high technology vs. low technology) according to stock markets, firm size, and technology level to test the firms' characteristics in relation to the value relevance of their donation and advertising expenditures.

\section{Empirical Analysis}

\subsection{Sample Selection}

This study obtained its sample data from the KIS-FAS (Korea Investors Service-Financial Analysis System) databases; the data cover the period from 2004 to 2011 and are drawn from listed Korean stock markets. This paper excludes firms without stock prices, book values, accounting earnings, donation expenditures, or advertising expenditures. This study also excludes financial banking, business firms, and the impairment of capital firms and removes outliers by excluding sample data with a Cook's Distance greater than 0.5 and an absolute value of studentized residuals greater than 1 . Table 1 presents the selected sample data and their sources. 
Table 1. Sample selection

\begin{tabular}{lc}
\hline Listed companies at the end of 2004-2011 (firm-year) & 14,046 \\
\hline Minus (-): & $(4,055)$ \\
1 Companies that do not settle their accounts in December & \\
2 Financial banking business & \\
3 Legal management firms & \\
4 Impairment of capital firms & 10,009 \\
Total sample firms (firm-year) & 3,767 \\
Large companies & 6,242 \\
Small \& Medium Companies & 10,009 \\
Total sample firms (firm-year) & 4,273 \\
Listed companies (KOSPI) & 5,734 \\
Unlisted companies (KOSDAQ) & 2 \\
External audit companies & 10,009 \\
Total sample firms (firm-year) & 4,730 \\
High-tech firms & 5,279 \\
Low-tech firms & 10,009 \\
Total sample firms (firm-year) &
\end{tabular}

\subsection{Empirical Analysis}

\subsubsection{Descriptive Statistics}

Table 2 presents the descriptive statistics of the sample firms' main variables. The dependent variable, $M V_{i, t}$, has a mean value of 20,036, a minimum value of 21 , and a maximum value of $1,707,000$. The independent variable, $N I_{i, t}$, has a mean value of 1,508 , a minimum value of $-56,641$, and a maximum value of 343,507 . The mean of $B V_{i, t-1}$ is 18,121 , and its maximum value is $1,821,292$. The mean of $D O N_{i, t}$ is 44.24872 , and the standard deviation is $458.7899 . A D_{i, t}$ has a mean value of 378.21309 , a minimum value of 0.0004401 , and a maximum value of 133,165 .

Table 2. Descriptive statistics

\begin{tabular}{ccccccc}
\hline Year & Number & Variables & Mean & Standard deviation & Min & Max \\
\hline & & $M V_{i, t}$ & 20,036 & 77,787 & 21 & $1,707,000$ \\
& & $N I_{i, t}$ & 1,508 & 8,497 & $-56,641$ & 343,507 \\
$2004-2011$ & \multirow{2}{*}{10,009} & $B V_{i, t-1}$ & 18,121 & 74,082 & 4.98716 & $1,821,292$ \\
& & $D O N_{i, t}$ & 44.24872 & 458.7899 & 0 & 36,925 \\
& & $A D_{i, t}$ & 378.21309 & 3,425 & 0.0004401 & 133,165 \\
\hline
\end{tabular}

Variable definitions: $\mathrm{MV}_{\mathrm{i}, \mathrm{t}}$ : stock price in the end of fiscal year $\mathrm{t}$, where year $\mathrm{t}$ is the event year, $\mathrm{BV}_{\mathrm{i}, \mathrm{t}-\mathrm{1}}$ : book value of equity at the end of year $t-1, \mathrm{NI}_{\mathrm{i}, \mathrm{t}}$ : accounting earnings in period $t, \mathrm{DON}_{\mathrm{i}, \mathrm{t}}$ : donation expenditure in period $t, \mathrm{AD}_{\mathrm{i}, \mathrm{t}}$ is defined as advertising expenditure in period $t$.

\subsubsection{Correlation Analysis}

Table 3 presents the Pearson correlation analysis between the dependent and independent variables of this paper. $\mathrm{MV}, \mathrm{NI}, \mathrm{BV}, \mathrm{DON}$, and $\mathrm{AD}$ are positively correlated at the $1 \%$ significance level. As some variables, such as MV, NI, and BV, show a high correlation, this paper tested for multicollinearity. The results indicate low multicollinearity by showing that all VIF (variance inflation factors) are smaller than 10 . Though the Pearson 
correlation analysis does not show the cause and effect between dependent and independent variables, these results demonstrate the strong possibility that independent variables such as NI, BV, DON, and AD are positively related to MV.

Table 3. Pearson correlations

\begin{tabular}{cccccc}
\hline Variables & MV & NI & BV & DON & AD \\
\hline MV & 1.00000 & & & & \\
NI & $0.68113^{* * *}$ & 1.00000 & & & \\
BV & $0.85646^{* * *}$ & $0.6698^{* * *}$ & 1.00000 & & \\
DON & $0.44062^{* * *}$ & $0.56809^{* * *}$ & $0.49974^{* * *}$ & 1.00000 & \\
AD & $0.57401^{* * *}$ & $0.41638^{* * *}$ & $0.54969^{* * *}$ & $0.12698^{* * *}$ & 1.00000 \\
\hline
\end{tabular}

1) Pearson's coefficient of correlation, two-sided test, Variable definitions: Refer to $<$ Table $2>$

2) $* \mathrm{p}<0.1, * * \mathrm{p}<0.05, * * * \mathrm{p}<0.01$

\subsubsection{Comparative Value Relevance of Donation and Advertising Expenditure: Total Firms}

Table 4 presents the value relevance of donation and advertising expenditures from 2004 to 2011 in listed Korean stock markets. This paper uses a modified Ohlson (1995) model that includes donation and advertising expenditures to investigate the comparative value relevance of the two variables.

The empirical results show that $\mathrm{R}^{2}$, indicating the explanatory validity of the empirical model, is $0.8629,0.8744$, and 0.8768 in models 1,2 , and 3 respectively. This result also shows that all independent variables (such as book value, earnings, donations, and advertising) are positively associated with the market value of equity at the $1 \%$ significance level. This result is similar to Kwon (2004), which reports the value relevance of book value and accounting earnings at the $1 \%$ significance level. The coefficient of donation is higher than that of advertising $(8.03662>1.13011)$, a result contrary to the common knowledge that advertising is done for business and donations are not.

Table 4. Comparative value relevance of donation and advertising expenditure: Total sample

\begin{tabular}{|c|c|c|c|c|}
\hline \multicolumn{2}{|c|}{$\begin{array}{c}\text { Variables } \\
\& \text { Expected Sign }\end{array}$} & \multicolumn{3}{|c|}{ Total Sample (10,009 firm-year) } \\
\hline Variables & Expected Sign & Model 1 & Model 2 & Model 3 \\
\hline Intercept & $?$ & $3220.11416^{* * *}$ & $3447.55296 * * *$ & $3342.47408^{* * *}$ \\
\hline $\mathrm{BV}$ & + & $0.70953 * * *$ & $0.63486 * * *$ & $0.62097 * * *$ \\
\hline NI & + & $2.01739 * * *$ & $2.23818^{* * *}$ & $2.18521 * * *$ \\
\hline DON & - & $8.03662 * * *$ & & $7.88982 * * *$ \\
\hline $\mathrm{AD}$ & + & & $1.13011^{* * *}$ & $1.18348 * * *$ \\
\hline \multicolumn{2}{|c|}{$\Sigma \mathrm{YD}$} & Included & Included & Included \\
\hline \multicolumn{2}{|c|}{$\Sigma \mathrm{IND}$} & Included & Included & Included \\
\hline \multicolumn{2}{|c|}{ F Value } & 7772.25 & 8595.26 & 7805.66 \\
\hline \multicolumn{2}{|c|}{ Adj R-Sq } & 0.8629 & 0.8744 & 0.8767 \\
\hline \multicolumn{2}{|c|}{ Number of sample } & 10,009 & 10,009 & 10,009 \\
\hline
\end{tabular}

1) Variable definition: refer to $<$ Table $2>$

2) Model 1: $M V_{i, t}=a_{0}+a_{1} B V_{i, t-1}+a_{2} N_{i, t}+a_{3} D O N_{i, t}+\varepsilon_{i, t}$,

3) Model 2: $M V_{i, t}=a_{0}+a_{1} B V_{i, t-1}+a_{2} N A_{i, t}+a_{3} A D_{i, t}+\varepsilon_{i, t}$ 
4) Model 3: $M V_{i, t}=a_{0}+a_{1} B V_{i, t-1}+a_{2} \operatorname{NIDA}_{i, t}+a_{3} D O N_{i, t}+a_{4} A D_{i, t}+\varepsilon_{i, t}$

5) $* \mathrm{p}<0.1, * * \mathrm{p}<0.05, * * * \mathrm{p}<0.01$

4.2.4 Comparative Value Relevance of Donation and Advertising Expenditures before and after GFC: Total Firms

Table 5 shows the comparative value relevance of donation and advertising expenditures before and after the 2007 global financial crisis, between 2004 and 2011, in Korean stock markets. To test whether the value relevance of donation and advertising expenditures is associated with the global financial crisis of 2008, this paper divides its sample into pre- and post-December 31, 2007, groups.

Table 6 displays the total number of samples (10,009 firm-years) from 2004 to 2011 in Korean stock markets. The empirical result shows that $\mathrm{R}^{2}$, which indicates the explanatory validity of the empirical model, is over 0.8619 in every model and both before and after the GFC. This result also shows that the independent variables (such as book value, earnings, donations, and advertising) are positively related to the market value of equity at a $1 \%$ significance level in every model and both before and after the GFC. This result is similar to that shown in Table 4 and in Kwon (2004), which shows that book value and accounting earnings are positively associated with firm value.

The coefficient of donation is higher than that of advertising before $(62.8231>1.65911)$ the GFC, but smaller than that of advertising after the GFC $(1.41847<3.87286)$, indicating that donations were more value relevant than advertising before the GFC and that advertising had more value relevance than donation in listed Korean stock markets after it. The Chow test supports these results, with the $\mathrm{F}$ value showing a $1 \%$ level of significance (110.49), indicating that the difference between the variables' coefficients before and after the GFC have a statistical significance. These results suggest that donations can increase firm value more than advertising in a steady state phase but that advertising has more power to promote company value than donations have in an economic crisis phase.

Table 5. Comparative value relevance of donation and advertising expenditure before and after GFC: Total firms

\begin{tabular}{|c|c|c|c|c|c|c|c|}
\hline \multirow{2}{*}{\multicolumn{2}{|c|}{$\begin{array}{c}\text { Variables } \\
\& \text { Expected Sign }\end{array}$}} & \multicolumn{6}{|c|}{ Total Sample(10,009 firm-year) } \\
\hline & & \multicolumn{3}{|c|}{ Before GFC } & \multicolumn{3}{|c|}{ After GFC } \\
\hline Variables & Expected Sign & Model 1 & Model 2 & Model 3 & Model 1 & Model 2 & Model 3 \\
\hline Intercept & $?$ & $2395.17114^{* * *}$ & $3913.63377 * * *$ & $2019.09174 * * *$ & $2186.4276^{* * *}$ & $3173.3141 * * *$ & $2570.16958 * * *$ \\
\hline BV & + & $0.61567 * * *$ & $0.54125^{* * *}$ & $0.59411 * * *$ & $0.74246^{* * *}$ & $0.59443 * * *$ & $0.61977 * * *$ \\
\hline NI & + & $2.90693 * * *$ & $3.33263 * * *$ & $2.76054 * * *$ & $1.8646^{* * *}$ & $1.95927 * * *$ & $2.2374 * * *$ \\
\hline DON & - & $62.8231 * * *$ & & $67.85928 * * *$ & $1.41847 * * *$ & & $-0.54047 * * *$ \\
\hline $\mathrm{AD}$ & + & & $1.65911 * * *$ & $-0.28963 * * *$ & & $3.87286^{* * *}$ & $2.93639 * * *$ \\
\hline \multicolumn{2}{|r|}{$\Sigma Y D$} & Included & Included & Included & Included & Included & Included \\
\hline \multicolumn{2}{|r|}{$\Sigma$ IND } & Included & Included & Included & Included & Included & Included \\
\hline \multicolumn{2}{|c|}{ F Value } & 3609.09 & 2373.26 & 5760.61 & 5354.39 & 5199.08 & 5013.24 \\
\hline \multicolumn{2}{|c|}{ Adj R-Sq } & 0.8619 & 0.8037 & 0.9179 & 0.8912 & 0.8883 & 0.8961 \\
\hline \multicolumn{2}{|c|}{ Number } & 4,702 & 4,702 & 4,702 & 5,307 & 5,307 & 5,307 \\
\hline \multicolumn{2}{|r|}{ Test } & \multicolumn{3}{|c|}{ Break Point } & \multicolumn{3}{|c|}{ F-Value } \\
\hline \multicolumn{2}{|r|}{ Chow } & & 4,702 & & & $110.49 * * *$ & \\
\hline
\end{tabular}
1) Variable definition: refer to $<$ Table $2>$
2) Model 1: $M V_{i, t}=a_{0}+a_{1} B V_{i, t-1}+a_{2} \operatorname{NID}_{i, t}+a_{3} D N_{i, t}+\varepsilon_{i, t}$,
3) Model 2: $M V_{i, t}=a_{0}+a_{1} B V_{i, t-1}+a_{2} N_{A} A_{i, t}+a_{3} A D_{i, t}+\varepsilon_{i, t}$
4) Model 3: $M V_{i, t}=a_{0}+a_{1} B V_{i, t-1}+a_{2} \operatorname{NIDA}_{i, t}+a_{3} D O N_{i, t}+a_{4} A D_{i, t}+\varepsilon_{i, t}$
5) $* \mathrm{p}<0.1, * * \mathrm{p}<0.05, * * * \mathrm{p}<0.01$ 
4.2.5 Comparative Value Relevance of Donation and Advertising Expenditures before and after the GFC: KOSPI Market

Table 6 presents the data on the comparative value relevance of donation and advertising expenditures before and after the 2007 global financial crisis from 2004 to 2011 in listed Korean stock markets (KOSPI). To examine the value relevance changes in the donation and advertising expenditures, this paper split the sample firms into pre- and post-December 31, 2007, groups.

Korean financial markets are classified into KOSPI and KOSDAQ markets; "KOSPI" stands for "Korea Composite Stock Price Index," and "KOSDAQ," for "Korea Securities Dealers Automated Quotation." The listed examination standard level of KOSPI is higher than that of KOSDAQ, and the firm size of KOSPI is larger than that of KOSDAQ.

Table 6 shows the total number of samples (4,273 firm-years) and the subgroups for before (2,083 firm-years) and after (2,190 firm-years) the GFC in KOSPI. The empirical results show that the $\mathrm{R}^{2} \mathrm{~s}$ are over 0.8536 in every model and both before and after the GFC in the KOSPI market. This result also shows that book value, earnings, donation, and advertising are positively associated with the market value of equity at the $1 \%$ significance level in every model before the GFC, while donations have a negative relationship with market value in model 3 after the GFC. This result is different from that shown in Table 4 and Table 5, in which all independent values are positively related to market value.

The donation coefficient is higher than that of advertising before $(60.79429>0.05619)$ the GFC, whereas the donation coefficient is smaller than that of advertising after the GFC $(2.61458<4.57795)$, and the donation coefficient shows negative estimates (-10.30385) in model 3 after the GFC.

These results indicate that donations are more value relevant than advertising before the GFC but that advertising has more value relevance than donations in KOSPI markets after it. The $\mathrm{F}$ value of the Chow test is significant at the $1 \%$ level (110.49), indicating that the coefficients of the donation and advertising expenditures before and after the GFC are significantly different, a result similar to that in Table 5. This suggests that a firm's donations can increase its market value more than its advertising in a steady state phase (before the GFC) and that advertising has more potential to promote firm value than do donations in an economic crisis phase (after the GFC).

Table 6. Comparative value relevance of donation and advertising expenditure before and after GFC: KOSPI market

\begin{tabular}{|c|c|c|c|c|c|c|c|}
\hline \multirow{2}{*}{\multicolumn{2}{|c|}{$\begin{array}{c}\text { Variables } \\
\& \text { Expected Sign }\end{array}$}} & \multicolumn{6}{|c|}{ KOSPI market (4,273 firm-year) } \\
\hline & & \multicolumn{3}{|c|}{ Before GFC } & \multicolumn{3}{|c|}{ After GFC } \\
\hline Variables & Expected Sign & Model 1 & Model 2 & Model 3 & Model 1 & Model 2 & Model 3 \\
\hline Intercept & $?$ & $-432.816^{* * *}$ & $3891.03811^{* * *}$ & $1244.62183^{* * *}$ & $2664.19423 * * *$ & $4864.24237 * * *$ & $4051.99884 * * *$ \\
\hline $\mathrm{BV}$ & + & $0.66649 * * *$ & $0.5816^{* * *}$ & $0.58515^{* * *}$ & $0.70437 * * *$ & $0.62221 * * *$ & $0.64562 * * *$ \\
\hline $\mathrm{NI}$ & + & $3.44155 * * *$ & $3.50584 * * *$ & $2.67054 * * *$ & $2.47854 * * *$ & $1.99723 * * *$ & $2.44475 * * *$ \\
\hline DON & - & $60.79429 * * *$ & & $71.58414 * * *$ & $2.61458 * * *$ & & $-10.30385 * * *$ \\
\hline $\mathrm{AD}$ & + & & $0.05619 * * *$ & $0.38024 * * *$ & & $4.57795 * * *$ & $3.36319 * * *$ \\
\hline \multicolumn{2}{|r|}{$\Sigma \mathrm{YD}$} & Included & Included & Included & Included & Included & Included \\
\hline \multicolumn{2}{|r|}{$\Sigma I N D$} & Included & Included & Included & Included & Included & Included \\
\hline \multicolumn{2}{|c|}{ F Value } & 2203.56 & 1488.89 & 2446.51 & 1810.83 & 1989.56 & 1868.59 \\
\hline \multicolumn{2}{|c|}{ Adj R-Sq } & 0.8961 & 0.8536 & 0.9151 & 0.8707 & 0.8810 & 0.8867 \\
\hline \multicolumn{2}{|c|}{ Number } & 2083 & 2083 & 2083 & 2190 & 2190 & 2190 \\
\hline \multicolumn{2}{|r|}{ Test } & \multicolumn{3}{|c|}{ Break Point } & \multicolumn{3}{|c|}{ F-Value } \\
\hline \multicolumn{2}{|r|}{ Chow } & \multicolumn{3}{|c|}{2083} & \multicolumn{3}{|c|}{$48321^{* * *}$} \\
\hline
\end{tabular}

1) Variable definition: refer to $<$ Table $2>$

2) Model 1: $M V_{i, t}=a_{0}+a_{1} B V_{i, t-1}+a_{2} N_{I} D_{i, t}+a_{3} D O N_{i, t}+\varepsilon_{i, t}$, 
3) Model 2: $M V_{i, t}=a_{0}+a_{1} B V_{i, t-1}+a_{2} N_{A} A_{i, t}+a_{3} A D_{i, t}+\varepsilon_{i, t}$

4) Model 3: $M V_{i, t}=a_{0}+a_{1} B V_{i, t-1}+a_{2} \operatorname{NIDA}_{i, t}+a_{3} D N_{i, t}+a_{4} A D_{i, t}+\varepsilon_{i, t}$

5) $* \mathrm{p}<0.1, * * \mathrm{p}<0.05, * * * \mathrm{p}<0.01$

4.2.6 Comparative Value Relevance of Donation and Advertising Expenditures before and after the GFC: KOSDAQ

Table 7 shows the comparative value relevance of donation and advertising expenditures before and after the 2007 global financial crisis from 2004 to 2011 in the KOSPI market. To test the value relevance changes in those donation and advertising expenditures, this study classifies all samples into pre- and post-December 31, 2007, groups.

Table 7 shows the total number of samples (5,734 firm-years) and subgroups (2,619 firm years before the GFC; 3,115 firm-years after the GFC) in the KOSPI market. The result shows that the $\mathrm{R}^{2} \mathrm{~s}$ are between 0.4887 and 0.5613 in every model and both before and after the GFC, lower results than those in Tables 5 and 6 . The $\mathrm{R}^{2}$ results indicate that the explanatory power of the main variables (such as book value, earnings, donation, and advertising) in the KOSDAQ is smaller than that in the KOSPI.

Table 7 also shows that book value, earnings, donations, and advertising are positively related to the market value of equity at the $1 \%$ significance level in every model before and after the GFC, a result similar to those shown in Tables 4 and 5. Table 7 also shows that the coefficients of donation expenditure are much higher than those of advertising both before $(15.32321>0.59853)$ and after $(41.11454>1.28871)$ the GFC.

Contrary to the results shown in Table 6 , these results suggest that donations are a more value relevant factor than advertising in both the pre- and post-GFC KOSDAQ markets. The pre- and post-GFC value relevance differences in donations and advertising are also supported by the $\mathrm{F}$ value of the Chow test, which is significant at the $1 \%$ level (2.71). This suggests that a firm's donations could increase market value more than advertising could in both the pre- and post-GFC KOSDAQ markets.

Table 7. Comparative value relevance of donation and advertising expenditure before and after GFC: KOSDAQ

\begin{tabular}{|c|c|c|c|c|c|c|c|}
\hline \multirow{2}{*}{\multicolumn{2}{|c|}{$\begin{array}{c}\text { Variables } \\
\text { \& Expected Sign }\end{array}$}} & \multicolumn{6}{|c|}{ KOSAQ (5,734 firm-year) } \\
\hline & & \multicolumn{3}{|c|}{ Before GFC } & \multicolumn{3}{|c|}{ After GFC } \\
\hline Variables & Expected Sign & Model 1 & Model 2 & Model 3 & Model 1 & Model 2 & Model 3 \\
\hline Intercept & $?$ & $3056.06335^{* * *}$ & $3112.15796^{* * *}$ & $3101.80252 * * *$ & $2835.68192 * * *$ & $2794.26465^{* * *}$ & $2917.49450 * * *$ \\
\hline BV & + & $0.49663 * * *$ & $0.42487 * * *$ & $0.41861 * * *$ & $0.45990^{* * *}$ & $0.45985^{* * *}$ & $0.42303 * * *$ \\
\hline NI & + & $2.42869 * * *$ & $2.21132 * * *$ & $2.18953 * * *$ & $2.16846^{* * *}$ & $1.89155^{* * *}$ & $1.79709^{* * *}$ \\
\hline DON & - & $15.32321 * * *$ & & $3.68975 * * *$ & $41.11454^{* * *}$ & & $14.77024 * * *$ \\
\hline \multirow[t]{8}{*}{$\mathrm{AD}$} & + & & $0.59853 * * *$ & $0.54598 * * *$ & & $1.28871 * * *$ & $1.10401 * * *$ \\
\hline & $\Sigma \mathrm{YD}$ & Included & Included & Included & Included & Included & Included \\
\hline & $\Sigma$ IND & Included & Included & Included & Included & Included & Included \\
\hline & Value & 308.85 & 382.58 & 340.46 & 490.65 & 385.33 & 336.24 \\
\hline & dj R-Sq & 0.4887 & 0.5426 & 0.5428 & 0.5613 & 0.5014 & 0.4966 \\
\hline & Number & 2,619 & 2,619 & 2,619 & 3,115 & 3,115 & 3,115 \\
\hline & Test & & Break Point & & & F-Value & \\
\hline & Chow & & 2,619 & & & $2.71^{* * *}$ & \\
\hline
\end{tabular}

1) Variable definition: refer to $<$ Table $2>$

2) Model 1: $M V_{i, t}=a_{0}+a_{1} B V_{i, t-1}+a_{2} N_{i, t}+a_{3} D O N_{i, t}+\varepsilon_{i, t}$,

3) Model 2: $M V_{i, t}=a_{0}+a_{1} B V_{i, t-1}+a_{2} N A_{i, t}+a_{3} A D_{i, t}+\varepsilon_{i, t}$

4) Model 3: $M V_{i, t}=a_{0}+a_{1} B V_{i, t-1}+a_{2} \operatorname{NIDA}_{i, t}+a_{3} D_{0 N} N_{i, t}+a_{4} A D_{i, t}+\varepsilon_{i, t}$ 
5) $* \mathrm{p}<0.1, * * \mathrm{p}<0.05, * * * \mathrm{p}<0.01$

4.2.7 Comparative Value Relevance of Donation and Advertising Expenditures before and after the GFC: Large Firms

Table 8 presents the comparative value relevance of donation and advertising expenditures before and after the 2007 global financial crisis from 2004 to 2011 for large firms. According to Korea's basic small enterprise law, firms with more than one thousand employees or assets amounting to more than 500 billion won (USD $550,000,000)$ are classified as "large" and others are "small and medium."

To examine the value relevance changes in large firms' donation and advertising expenditures before and after the GFC, this paper classifies the large firm sample into pre- and post-December 31, 2007, groups. Table 8 shows the total big firm sample (3,767 firm-years) and its subgroups (1,835 firm-years before the GFC; 1,932 firm-years after the GFC).

All the $\mathrm{R}^{2} \mathrm{~s}$ are over 0.8423 in every model both pre- and post-GFC, These are similar to the results in the total sample and in the KOSPI group (see Tables 5 and 6), but much higher than in the KOSDAQ samples (see Table 7). Table 8 also shows that donation expenditures are positively associated with firm value (58.99558), whereas advertising has a negative value relevance $(-0.2437)$ at the $1 \%$ significance level before the GFC. Similarly, donations are positively associated with firm value $(5.89785)$, while advertising has a negative value relevance $(-0.2437)$ at a $1 \%$ significance level after the GFC.

These results show that donations have more value relevance than advertising both before and after the GFC in large firms. The difference in the value relevance of donation and advertising expenditures before and after the GFC is supported by the F value of the Chow test, which is significant at the $1 \%$ level (41.52), indicating that large firms' donations increased their market value more than their advertising both before and after the GFC. This result differs from this study's prediction and the results of previous studies (Peles, 1971; Abdel-Khalik, 1975; Clarke, 1976; Hirschey and Weygandt, 1985; Lee, 1994; White and Miles, 1996; Cho and Jung, 2001; Paek and Jeon, 2004; Chung and Cho, 2004; Cho and Ryu, 2006; Lee and Choi, 2007; Huh et al., 2007), which report that advertising is positively associated with firm value.

Table 8. Comparative value relevance of donation and advertising expenditure before and after GFC: Large firm

\begin{tabular}{|c|c|c|c|c|c|c|c|}
\hline & Variables & & & Large Firm (3, & 767 firm-year) & & \\
\hline \& Ex & xpected Sign & & Before GFC & & & After GFC & \\
\hline Variables & s Expected Sign & Model 1 & Model 2 & Model 3 & Model 1 & Model 2 & Model 3 \\
\hline Intercept & $?$ & $1691.24268 * * *$ & $5728.83451^{* * *}$ & $2707.69009^{* * *}$ & $5141.26693 * * *$ & $6339.02103^{* * *}$ & $5300.78685^{* * *}$ \\
\hline BV & + & $0.66308 * * *$ & $0.57285^{* * *}$ & $0.58158^{* * *}$ & $0.71470 * * *$ & $0.64024 * * *$ & $0.65037 * * *$ \\
\hline NI & + & $3.56548 * * *$ & $3.7193 * * *$ & $2.8487 * * *$ & $2.37440 * * *$ & $1.97884 * * *$ & $2.45144 * * *$ \\
\hline DON & - & $58.99558^{* * *}$ & & $73.16472 * * *$ & $5.89785^{* * *}$ & & $-1.56128^{* * *}$ \\
\hline $\mathrm{AD}$ & + & & $-0.2437 * * *$ & $-0.02376^{* * *}$ & & $-0.2437 * * *$ & $1.95727 * * *$ \\
\hline & $\Sigma Y D$ & Included & Included & Included & Included & Included & Included \\
\hline & $\Sigma I N D$ & Included & Included & Included & Included & Included & Included \\
\hline & F Value & 1895.3 & 1201.18 & 1939.73 & 1815.02 & 1551.17 & 1261.24 \\
\hline & Adj R-Sq & 0.8941 & 0.8423 & 0.9065 & 0.8845 & 0.8674 & 0.8569 \\
\hline & Number & 1,835 & 1,835 & 1,835 & 1,932 & 1,932 & 1,932 \\
\hline & Test & & Break Point & & & F-Value & \\
\hline & Chow & & 1,835 & & & $41.52 * * *$ & \\
\hline
\end{tabular}

1) Variable definition: refer to $<$ Table $2>$

2) Model 1: $M V_{i, t}=a_{0}+a_{1} B V_{i, t-1}+a_{2} N_{i, t}+a_{3} D_{i, t}+\varepsilon_{i, t}$,

3) Model 2: $M V_{i, t}=a_{0}+a_{1} B V_{i, t-1}+a_{2} N_{I A} A_{i, t}+a_{3} A D_{i, t}+\varepsilon_{i, t}$ 
4) Model 3: $M V_{i, t}=a_{0}+a_{1} B V_{i, t-1}+a_{2} \operatorname{NIDA}_{i, t}+a_{3} D O N_{i, t}+a_{4} A D_{i, t}+\varepsilon_{i, t}$

5) $* \mathrm{p}<0.1, * * \mathrm{p}<0.05, * * * \mathrm{p}<0.01$

4.2.8 Comparative Value Relevance of Donation and Advertising Expenditures before and after the GFC: Small and Medium Firms

Table 9 shows the comparative value relevance of pre- and post-GFC donation and advertising expenditures from 2004 to 2011 for small and medium firms. To investigate the changes in the value relevance of donation and advertising expenditures, the study divides the small and medium group into two pre- and post-December 31, 2007, subgroups. Table 9 shows the total number of small and medium firm samples (6,242 firm-years) and the subgroups (2,867 firm-years before the GFC; 3,375 firm-years after the GFC).

The $\mathrm{R}^{2} \mathrm{~s}$ of model 1, 2, and 3 show the estimates above 0.6017 both before and after the GFC, similar to the estimates of the KOSDAQ group (see Table 7). Table 9 also shows that donation and advertising expenditures are positively related to company value before and after the GFC. The value relevance of donations is much higher than that of advertising before the GFC $(12.80328>3.53605)$, whereas the value relevance of advertising is higher than that of donations after the GFC $(3.10695>1.49918)$.

These results are supported by the $\mathrm{F}$ value of the Chow test, which is significant at the $1 \%$ level (6.02), as presented in Table 9. This suggests that a small and medium firm's donations had more of a potential to promote the market value of its equity than its advertising both before and after the GFC and that advertising had more value relevance than donation after the GFC.

Table 9. Comparative value relevance of donation and advertising expenditure before and after GFC: Small \& medium firm

\begin{tabular}{|c|c|c|c|c|c|c|c|}
\hline \multirow{2}{*}{\multicolumn{2}{|c|}{$\begin{array}{c}\text { Variables } \\
\& \text { Expected Sign }\end{array}$}} & \multicolumn{6}{|c|}{ Small \& Medium Firm $(6,242)$} \\
\hline & & \multicolumn{3}{|c|}{ Before GFC } & \multicolumn{3}{|c|}{ After GFC } \\
\hline \multicolumn{2}{|c|}{ Variables Expected Sign } & Model 1 & Model 2 & Model 3 & Model 1 & Model 2 & Model 3 \\
\hline Intercept & $?$ & $2726.38238^{* * *}$ & $2598.38532 * * *$ & $2594.77324 * * *$ & $2523.70384^{* * *}$ & $2367.68992 * * *$ & $2332.61550^{* * *}$ \\
\hline $\mathrm{BV}$ & + & $0.39059 * * *$ & $0.40233 * * *$ & $0.39114 * * *$ & $0.37856^{* * *}$ & $0.37755^{* * *}$ & $0.38272 * * *$ \\
\hline NI & + & $1.41566^{* * *}$ & $1.43811^{* * *}$ & $1.38471 * * *$ & $1.92287^{* * *}$ & $1.89812 * * *$ & $1.88065^{* * *}$ \\
\hline DON & - & $12.80328 * * *$ & & $8.43466 * * *$ & $1.49918 * * *$ & & $-4.72749 * * *$ \\
\hline $\mathrm{AD}$ & + & & $3.53605^{* * *}$ & $3.11443^{* * *}$ & & $3.10695 * * *$ & $3.30662 * * *$ \\
\hline \multicolumn{2}{|c|}{$\Sigma \mathrm{YD}$} & Included & Included & Included & Included & Included & Included \\
\hline \multicolumn{2}{|c|}{$\Sigma I N D$} & Included & Included & Included & Included & Included & Included \\
\hline \multicolumn{2}{|c|}{ F Value } & 530.84 & 546.96 & 485.42 & 787.38 & 803.62 & 707.81 \\
\hline \multicolumn{2}{|c|}{ Adj R-Sq } & 0.6017 & 0.6087 & 0.6082 & 0.6550 & 0.6596 & 0.6577 \\
\hline \multicolumn{2}{|c|}{ Number } & 2,867 & 2,867 & 2,867 & 3,375 & 3,375 & 3,375 \\
\hline \multicolumn{2}{|c|}{ Test } & \multicolumn{3}{|c|}{ Break Point } & \multicolumn{3}{|c|}{ F-Value } \\
\hline \multicolumn{2}{|c|}{ Chow } & & 2,867 & & & $6.02 * * *$ & \\
\hline
\end{tabular}

1) Variable definition: refer to $<$ Table $2>$

2) Model 1: $M V_{i, t}=a_{0}+a_{1} B V_{i, t-1}+a_{2} N_{i, t}+a_{3} D N_{i, t}+\varepsilon_{i, t}$,

3) Model 2: $M V_{i, t}=a_{0}+a_{1} B V_{i, t-1}+a_{2} N_{A} A_{i, t}+a_{3} A D_{i, t}+\varepsilon_{i, t}$

4) Model 3: $M V_{i, t}=a_{0}+a_{1} B V_{i, t-1}+a_{2} \operatorname{NIDA}_{i, t}+a_{3} D O N_{i, t}+a_{4} A D_{i, t}+\varepsilon_{i, t}$

5) $* \mathrm{p}<0.1, * * \mathrm{p}<0.05, * * * \mathrm{p}<0.01$ 
4.2.9 Comparative Value Relevance of Donation and Advertising Expenditures before and after the GFC: High-Tech Firms

Table 10 shows whether donations or advertising expenditures had more value relevance and which was the more value relevant factor in both the pre- and post-GFC periods, from 2004 to 2011, for high-technology firms. To investigate the value relevance changes and the comparative value relevance of donation and advertising expenditures before and after the GFC, this paper splits the sample into the high-tech and low-tech company groups. Then, the paper investigates the value relevance change and comparative value relevance of donation and advertising expenditures before and after the GFC.

This paper divides its sample into high- and low-technology firm groups according to Himmelberg and Petersen (1994), who define the chemical, pharmaceutical, metal, electronic component, medical, precision and optical instruments, and electrical equipment industries as comprising the high-technology industry and the other industries as comprising the low-technology industry.

Table 10 shows the total number of high-tech firm samples (4,730 firm-years) and their subgroups $(2,177$ firm-years before the GFC; 2,553 firm-years after the GFC). The $\mathrm{R}^{2} \mathrm{~s}$ of models 1,2 , and 3 are above 0.7982 both before and after the GFC. Table 10 shows that donation and advertising expenditures are positively associated with firm value before and after the GFC. The value relevance of donation expenditures is higher than that of advertising both before $(74.49984>10.44624)$ and after the GFC $(24.30043>18.36903)$. The F value of the Chow test, at a 1\% significance level (69.96), supports the value relevance difference between donation and advertising expenditures and indicates that a firm's donation activity had more value relevance than advertising activity did both before and after the GFC for high-tech firms.

Table 10. Comparative value relevance of donation and advertising expenditure before and after GFC: High-tech firm

\begin{tabular}{|c|c|c|c|c|c|c|c|}
\hline \multirow{2}{*}{\multicolumn{2}{|c|}{$\begin{array}{c}\text { Variables } \\
\& \text { Expected Sign }\end{array}$}} & \multicolumn{6}{|c|}{ High-tech Firm (4,730 firm-year) } \\
\hline & & \multicolumn{3}{|c|}{ Before GFC } & \multicolumn{3}{|c|}{ After GFC } \\
\hline \multicolumn{2}{|c|}{ Variables Expected Sign } & Model 1 & Model 2 & Model 3 & Model 1 & Model 2 & Model 3 \\
\hline Intercept & $?$ & $-343.38838 * * *$ & $3643.22387 * * *$ & $1890.46541^{* * *}$ & $-3226.46748 * * *$ & $1403.68251 * * *$ & $996.02745^{* * *}$ \\
\hline BV & + & $0.6401 * * *$ & $0.57861^{* * *}$ & $0.51256^{* * *}$ & $0.83291 * * *$ & $0.56118 * * *$ & $0.53411 * * *$ \\
\hline NI & + & $2.78137^{* * *}$ & $3.24649 * * *$ & $2.69918^{* * *}$ & $2.09488 * * *$ & $1.65960 * * *$ & $1.51990^{* * *}$ \\
\hline DON & - & $74.49984 * * *$ & & $59.98223 * * *$ & $24.30043 * * *$ & & $20.31425^{* * *}$ \\
\hline $\mathrm{AD}$ & + & & $10.44624 * * *$ & $7.002 * * *$ & & $18.36903^{* * *}$ & $17.96342^{* * *}$ \\
\hline \multicolumn{2}{|c|}{$\Sigma Y \mathrm{D}$} & Included & Included & Included & Included & Included & Included \\
\hline \multicolumn{2}{|c|}{$\Sigma \mathrm{IND}$} & Included & Included & Included & Included & Included & Included \\
\hline \multicolumn{2}{|c|}{ F Value } & 4246.18 & 1412.67 & 1448.17 & 1926.00 & 5297.66 & 2517.56 \\
\hline \multicolumn{2}{|c|}{ Adj R-Sq } & 0.9221 & 0.7982 & 0.8258 & 0.8204 & 0.9270 & 0.8757 \\
\hline \multicolumn{2}{|c|}{ Number } & 2,177 & 2,177 & 2,177 & 2,553 & 2,553 & 2,553 \\
\hline \multicolumn{2}{|c|}{ Test } & \multicolumn{3}{|c|}{ Break Point } & \multicolumn{3}{|c|}{ F-Value } \\
\hline \multicolumn{2}{|c|}{ Chow } & & 2,177 & & & $69.96 * * *$ & \\
\hline
\end{tabular}

1) Variable definition: refer to $<$ Table $2>$

2) Model 1: $M V_{i, t}=a_{0}+a_{1} B V_{i, t-1}+a_{2} \operatorname{NID}_{i, t}+a_{3} D N_{i, t}+\varepsilon_{i, t}$,

3) Model 2: $M V_{i, t}=a_{0}+a_{1} B V_{i, t-1}+a_{2} N_{A} A_{i, t}+a_{3} A D_{i, t}+\varepsilon_{i, t}$

4) Model 3: $M V_{i, t}=a_{0}+a_{1} B V_{i, t-1}+a_{2} \operatorname{NIDA}_{i, t}+a_{3} D N_{i, t}+a_{4} A_{i, t}+\varepsilon_{i, t}$

5) $*$ p $<0.1, * * p<0.05, * * * p<0.01$ 
4.2.10 Comparative Value Relevance of Donation and Advertising Expenditures before and after the GFC: Low-Tech Firms

This section examines the value relevance change and the comparative value relevance of donation and advertising expenditures from 2004 to 2011 in the low technology firm group.

Table 11 shows the total number of low-tech firm samples (5,279 firm-years) and subgroups (2,525 firm-years before the GFC; 2,754 firm-years after the GFC). All $\mathrm{R}^{2} \mathrm{~s}$ in models 1, 2, and 3 show estimates above 0.8513 both before and after the GFC. Table 11 also shows that donation expenditure is positively associated with firm value, while advertising expenditure is negatively associated with company value before and after the GFC. The result also shows that the value relevance of donation expenditures is much higher than that of advertising both before (43.76693 > -0.46831) and after the GFC (11.97270 > -2.49709) for low-tech companies. The F value of the Chow test, at a $1 \%$ significance level (59.66), supports the superiority of donation expenditure in the valuation. This result provides evidence that a firm's donation activity was significantly associated with firm value whereas a firm's advertising activity had a negative effect on company value both before and after the GFC in low-tech firms, contrary to the expectation of this paper and previous studies (Peles, 1971; Abdel-Khalik, 1975; Clarke, 1976; Hirschey \& Weygandt, 1985; Lee, 1994; White \& Miles, 1996; Cho \& Jung, 2001; Paek \& Jeon, 2004; Jung \& Cho, 2004; Cho \& Ryu, 2006; Lee \& Choi, 2007; Huh et al., 2007), which found that advertising has a positive value relevance.

Table 11. Comparative value relevance of donation and advertising expenditure before and after GFC: Low-tech firm

\begin{tabular}{|c|c|c|c|c|c|c|c|}
\hline \multirow{2}{*}{\multicolumn{2}{|c|}{$\begin{array}{c}\text { Variables } \\
\& \text { Expected Sign }\end{array}$}} & \multicolumn{6}{|c|}{ Low-tech Firm (5,279 firm-year) } \\
\hline & & \multicolumn{3}{|c|}{ Before GFC } & \multicolumn{3}{|c|}{ After GFC } \\
\hline Variables & Expected Sign & Model 1 & Model 2 & Model 3 & Model 1 & Model 2 & Model 3 \\
\hline Intercept & $?$ & $1955.42985 * * *$ & $4399.22171 * * *$ & $3008.38244 * * *$ & $2430.78423 * * *$ & $2701.77179 * * *$ & $2489.72849 * * *$ \\
\hline BV & + & $0.69312 * * *$ & $0.53102 * * *$ & $0.5401 * * *$ & $0.68589 * * *$ & $0.72549 * * *$ & $0.69406^{* * *}$ \\
\hline NI & + & $3.29775 * * *$ & $3.29631 * * *$ & $2.81358^{* * *}$ & $2.14925 * * *$ & $1.98980 * * *$ & $1.98397 * * *$ \\
\hline DON & - & $43.76693 * * *$ & & $51.91257 * * *$ & $11.97270 * * *$ & & $13.48676^{* * *}$ \\
\hline \multirow[t]{2}{*}{$\mathrm{AD}$} & + & & $-0.46831 * * *$ & $0.19126^{* * *}$ & & $-2.49709 * * *$ & $-2.31757 * * *$ \\
\hline & $\Sigma Y D$ & Included & Included & Included & Included & Included & Included \\
\hline \multicolumn{2}{|r|}{$\Sigma I N D$} & Included & Included & Included & Included & Included & Included \\
\hline \multicolumn{2}{|c|}{ F Value } & 1905.58 & 1774.15 & 2020.3 & 3732.94 & 3845.48 & 3440.29 \\
\hline \multicolumn{2}{|c|}{ Adj R-Sq } & 0.8603 & 0.8513 & 0.8801 & 0.9170 & 0.9193 & 0.9197 \\
\hline \multicolumn{2}{|c|}{ Number } & 2,525 & 2,525 & 2,525 & 2,754 & 2,754 & 2,754 \\
\hline \multicolumn{2}{|r|}{ Test } & \multicolumn{3}{|c|}{ Break Point } & \multicolumn{3}{|c|}{ F-Value } \\
\hline \multicolumn{2}{|r|}{ Chow } & \multicolumn{3}{|c|}{2,525} & \multicolumn{3}{|c|}{$59.66 * * *$} \\
\hline
\end{tabular}

1) Variable definition: refer to $<$ Table $2>$

2) Model 1: $M V_{i, t}=a_{0}+a_{1} B V_{i, t-1}+a_{2} \operatorname{NID}_{i, t}+a_{3} D N_{i, t}+\varepsilon_{i, t}$,

3) Model 2: $M V_{i, t}=a_{0}+a_{1} B V_{i, t-1}+a_{2} N_{A} A_{i, t}+a_{3} A D_{i, t}+\varepsilon_{i, t}$

4) Model 3: $\mathrm{MV}_{\mathrm{i}, \mathrm{t}}=\mathrm{a}_{0}+\mathrm{a}_{1} \mathrm{BV}_{\mathrm{i}, \mathrm{t}-1}+\mathrm{a}_{2} \mathrm{NIDA}_{\mathrm{i}, \mathrm{t}}+\mathrm{a}_{3} \mathrm{DON}_{\mathrm{i}, \mathrm{t}}+\mathrm{a}_{4} \mathrm{AD}_{\mathrm{i}, \mathrm{t}}+\varepsilon_{\mathrm{i}, \mathrm{t}}$

5) $*$ p $<0.1, * *$ p $<0.05, * * * p<0.01$

\section{Conclusions}

This paper investigates the comparative value relevance of and value relevance change between donation and advertising expenditures from 2004 to 2011 in the Korean stock market to compare the value relevance change between donation and advertising expenditures before and after the GFC. To do this, it classifies its sample data 
according to firm characteristics such as market, size, and technology level. This paper proposes two hypotheses, $\mathrm{H}-1$ (the value relevance of donation expenditures before and after the GFC differ) and $\mathrm{H}-2$ (the value relevance of advertising expenditures before and after the GFC differ) and designs empirical models replicating the theory in Myer (1977) and the model in Ohlson (1995) by including donation and advertising expenditures.

The empirical model of this paper shows that hypotheses 1 and 2 are significantly supported as applied to Korea's stock markets. The test results concerning the comparative value relevance of donation and advertising expenditures are unexpected, however.

First, the examination of the total sample involving the independent variables (donation and advertising expenditures) shows their positive association with firm value at the $1 \%$ significance level, but the comparative value relevance contradicts the general expectation that advertising occurs for business purposes while donations do not: donation expenditures show a higher value relevance than do advertising expenditures in all sample firms.

Second, this paper divides its sample into two subgroups (pre- and post-GFC) to investigate value relevance changes after the global financial crisis. As in the overall test results, donation and advertising expenditures show significant value relevance, but the detailed results differ. Donation expenditures display much higher value relevance than advertising before the GFC while advertising shows higher value relevance than donations after the GFC, suggesting that economic crises such as the GFC impact the value relevance of donations and advertising and that donations can increase firm value more than advertising in a steady state (as from 2004 to 2007), whereas advertising, which focusses on business, can promote firm value more than donations can in economic crises (as from 2008 to 2011).

Third, this study extracts firms in the KOSPI and KOSDAQ markets to test the comparative value relevance of and value relevance change between donation and advertising expenditures. The results show that donation expenditures had much higher value relevance than advertising did before the GFC in the KOSPI market, but that advertising had higher value relevance than donations did after the GFC, suggesting that economic crises such as the GFC has a significant effect on the value relevance of donation and advertising activities. As in the empirical results described above, this result also shows that donations enhance firm value more than advertising does in a steady state (as from 2004 to 2007) and that advertising can promote firm value more than donations can in a financial crisis state (as from 2008 to 2011) in a KOSPI market. Donation expenditures have more value relevance than advertising expenditures in the KOSAQ than in the KOSPI group both before and after the GFC, indicating that the comparative value relevance of donation and advertising expenditures changes according to the financial market a firm belongs to.

Fourth, this study extracts both large and small and medium firms from the sample to examine the comparative value relevance of and value relevance change between their donation and advertising expenditures. The results show that donation expenditures had much higher value relevance than advertising expenditures and that advertising had a negative value relevance, both before and after the GFC in large firms. For small and medium firms, advertising had positive value relevance at a $1 \%$ significance level both pre- and post-GFC. In addition, advertising had more value relevance than donations did after the GFC in small and medium firms. These results suggest that the global economic crisis had a significant effect on the value relevance of the donation and advertising activities of small and medium firms, while the GFC had no effect on their value relevance in large firms.

Fifth, this paper extracts high- and low-tech firms from the samples to investigate the comparative value relevance of and value relevance change between their donation and advertising expenditures. The results show that donation expenditures had much higher value relevance than advertising did both before and after the GFC in high-tech firms, with the same result seen in low-tech firms. Advertising expenditures have a negative value relevance both before and after the GFC in low-tech companies, contradicting this study's general expectation and the literature. This result suggests that the comparative value relevance of donation and advertising expenditures changes according to the level of a firm's technology. Nevertheless, this paper has a limitation. It fails to cover a large sample of countries (e.g., the U.S. China, Japan). It will be necessary to extend the coverage of the sample to include more global companies.

\section{References}

Abdel-khalik, A. R. (1975). Advertising Effectiveness and Accounting Policy. The Accounting Review, 50(Supplement), 657-670. 
Ahn, H. B., \& Kwon, G. J. (2006). An Analysis on Firm's Value based the Innovation of R\&D. Korean Accounting Review, 31(3), 27-61 [Printed in Korean].

Bae, J, H., Kim, B. D., \& Kim, J. H. (2008). The Effect of Corporate Social Investment on the Market Value of a Korean Firm: An Event-Study Methodology. Korean Journal of Management, 16(2), 159-192. [Printed in Korean]

Barth, M. E., Beaver, W. H., \& Landsman, W. R. (1998). Relative Valuation Roles of Equity Book Value and Net Income as a Function of Financial Health. Journal of Accounting and Economics, 25, 1-34. http://dx.doi.org/10.1016/S0165-4101(98)00017-2

Bernard, V. L., \& Stober, T. (1989). The nature and Amount of Information in Cash Flows and Accruals. The Accounting Review, 64, 624-652.

Biddle, G., Seow, G., \& Siegel, A. (1995). Relative versus Incremental Information Content. Contemporary Accounting Research, 12, 1-23. http://dx.doi.org/10.1111/j.1911-3846.1995.tb00478.x

Black, E. L. (1998). Which is more Value Relevant: Earnings or Cash Flows? A Life Cycle Examination, Working Paper. University of Arkansas, Fayetteville, Arkansas.

Brown, W., Hellan, E., \& Smith, K. (2006). Corporate Philanthropic Practices. Journal of Corporate Finance, 12, 855-877. http://dx.doi.org/10.1016/j.jcorpfin.2006.02.001

Bublitz, B., \& Ettredge, M. (1989). The Information in Discretionary Outlays: Advertising and Research and Development. Accounting Review, 64, 108-124.

Bublitz, B., \& Ettredge, M. (1989). The Information in Discretionary Outlays: Advertising and Research and Development. Accounting Review, 64, 108-124.

Chauvin, K. W., \& Hirschey, M. (1993, Winter). Advertising, R\&D Expenditures and the Market Value of the Firm. Financial Management, 128-140. http://dx.doi.org/10.2307/3665583

Cho, S. P., \& Jung, J. Y. (2001, February). Multi-period Effect of R \& D Expenditures on Accounting Income. Korean Management Review, 289-310. [Printed in Korean]

Cho, S. P., \& Ryu, J. H. (2006). Brand Familiarity and Differential Earning Effect of Advertising and R\&D Expenditures. The Accounting Review, 31(4), 25-52. [Printed in Korean]

Choi, J. H. (1994). The Value Relevance of Advertising and R\&D expenditure - Empirical Analysis using Torbin-Q. The Accounting Review, 19, 103-124. [Printed in Korean]

Choi, J. H., Kim, J. B., \& Lee, J. J. (2011). Value Relevance of Discretionary Accruals in the Asian financial Crisis of 1997-1998. Journal of Accounting and Public Policy, 30(2), 166-187. [Printed in Korean] http://dx.doi.org/10.1016/j.jaccpubpol.2010.09.002

Choi, K., \& Choi, S. H. (2010). The Effect of Economic Crisis on the Value Relevance of Accounting Information. Korean Accounting Journal, 19(3), 103-124. [Printed in Korean]

Choi, S. P., \& Jung, J. Y. (2001, February). Multi-period Effect of R\&D Expenditures on Accounting Income. Korean Management Review, 289-310 [Printed in Korean].

Choi, W. W., Bae, J. H., \& Kim, S. I. (2009). The Effect of Charitable Contributions on the Firm Value - from the Perspective of Corporate Ownership. Korean Management Review, 40(3), 1415-1443. [Printed in Korean]

Choi, W. Y., \& Lee, H. S. (2009). Determinants of Corporate Philanthropy: Application of Several Econometric Methodologies. Sojang Journal of Business, 20(1), 139-152. [Printed in Korean]

Choi, W. Y., Lee, H. S., \& Hong, C. S. (2009). Corporate Social Responsibility and Firm Value: Focused on Corporate Contributions. Korean Management Review, 38(2), 407-432. [Printed in Korean]

Chung, H. Y., \& Cho, S. I. (2004). Value-Relevance of Accounting Information on Intangibles. Korean Accounting Review, 29(3), 1-31 [Printed in Korean].

Clarke, D. G. (1976, November). Econometric Measurement of the Duration of Advertising Effect on Sales. Journal of Marketing Research, 13(4), 347-357. http://dx.doi.org/10.2307/3151017

Collins, D. W., Maydew, E., L., \& Weiss, I. S. (1997). Changes in the Value-Relevance of Earnings and Book Values over the Past Forty Years. Journal of Accounting and Economics, 24(1), 39-67. http://dx.doi.org/10.1016/S0165-4101(97)00015-3 
Davis-Friday, P. Y., Eng, L. L., \& Chao-Shin, L. (2006). The Effects of the Asian Crisis, Corporate Governance and Accounting System on the Valuation of Book Value and Earnings. The International Journal of Accounting, 41(1), 22-40. http://dx.doi.org/10.1016/j.intacc.2005.12.002

Fishman, R., Heal, G., \& Nair, V. B. (2006). A Model of Corporate Philanthropy. Working Paper, University of Pennsylvania.

Fombrun, C. J., \& Shanley, M. (1990). What's in a Name? Reputation Building and Corporate Strategy. Academy of Management Journal, 33(2), 233-258. http://dx.doi.org/10.2307/256324

Graham, R., King, R., \& Bailes, J. (2000). The Value Relevance of Accounting Information during a Financial Crisis: Thailand and the 1997 Decline in the Value of the Baht. Journal of International Financial Management and Accounting, 11(2), 84-107. http://dx.doi.org/10.1111/1467-646X.00057

Griliches, Z., \& Mairesse, J. (1984). Productivity and R\&D at Firm Level. In Z. Griliches (Ed.), R\&D, Patent and Productivity (pp. 339-374). Chicago: Univ. of Chicag Press. http://dx.doi.org/10.7208/chicago/9780226308920.001.0001

Guo, R. J., Lev, B., \& Shi, C. (2006). Explaining the Short- and Long-Term Ipo Anomalies in the Us by R\&D. $\begin{array}{llll}\text { Journal of Business Finance \& Accounting, 33(3-4), 550-579. } & \text {. }\end{array}$ http://dx.doi.org/10.1111/j.1468-5957.2006.00610.x

Hall, B. H. (1993). Dynamics of Science-Based Innovation in North America, Japan and Western Europe (Edited by Okamura, S., Sakuci, F., \& Nonaka, I.).

Himmelberg, C. P., \& Petersen, B. C. (1994). R\&D and Internal Finance: a Panel Study of Small firms in High-Tech Industries. Review of Economics and Statistics, 76, 38-51. http://dx.doi.org/10.2307/2109824

Hirschey, M. (1982). Intangible Capital Aspects of Advertising and R\&D Expenditures. Journal of Accounting Research, 30, 375-390.

Hirschey, M., \& Weygandt, J. (1985, Spring). Amortization Policy for Advertising and Research and Development Expenditures. Journal of Accounting Research, 23, 326-335. http://dx.doi.org/10.2307/2490921

Huh, H, Lee, J. G., \& Kim, Y. K. (2007). The Effects of the R\&D and Advertising Expenditures on the Corporate Value. Journal of Financial Engineering, 6(1), 1-16. [Printed in Korean]

Janice, L., \& John, P. (2008). Post-Asian Financial Crisis Reforms: An Emerging New Embedded Relational Governance Model. Accounting, Business \& Financial History, 18(3), 335-355. http://dx.doi.org/10.1080/09585200802383455

Johnson, S., Boone, P., Breach, A., \& Friedman, E. (2000). Corporate Governance in the Asian Financial Crisis. Journal of Financial Economics, 58(1-2), 141-186. http://dx.doi.org/10.1016/S0304-405X(00)00069-6

Jung, K. S., \& Lee, J. G. (1996). The Effects of Advertising and R\&D Expenditures on the Market Value of the Firm. Review of Business \& Economics, 9(1), 395-417. [Printed in Korean]

Keller, K. L., \& Lehmann, D. R. (2003). How Do Brand Create Value? Marketing Management, 12, 26-31.

Kim, C. S., Hong, J. H., \& Kim, W. H. (2008). The Analysis on the Impact of Corporation's Ownership Structure on the Level of Contributions. Journal of Taxation and Accounting, 9(2), 105-126. [Printed in Korean]

Kim, H. G., \& Choi, J. Y. (2011). The Relationship between Corporate Social Responsibility and Financial Performance. Journal of Accounting Information, 29(2), 105-126. [Printed in Korean]

Kim, S. H., \& Kim, M. N. (2011). The Effect of Firms' Contribution Expenses and Catering Expenses on Their Profitability in Korea: Theory and Evidence. Korean Management Review, 40(3), 659-685. [Printed in Korean]

Kim, Y. Y., Chang, W. K., \& Ki, H. H. (2006). A Study on the Impact of the Intangible Assets on the Firm Value. Korean Journal of Business Administration, 19(1), 199-216. [Printed in Korean]

Kwon, G. J. (2004). An Empirical Analysis on the Relevance of Accounting Income and Book Value Using Option-Style Model of Equity Value. Doctoral Dissertation, Kyungpook National University. [Printed in Korean]

Kwon, S. Y., \& Lee, S. H. (1999). The Impact of R\&D Costs and Advertising Expenditures on the Firms' Market Value. Journal of Business Research, 14(2), 239-263. [Printed in Korean] 
Lee, K. B., \& Choi, M. H. (2007). Determinants of Abnormal Income. Journal of Business Research, 22(4), 175-208. [Printed in Korean]

Lee, S. M. (1994). An Empirical Study on the Predictability of R\&D Costs and Advertising Expenditures to the Accounting Income. Doctoral Dissertation, Dankook University. [Printed in Korean]

Lev, B., Christine, P., \& Suresh, R. (2006). Is Doing Good Good for You? Yes, Charitable Contributions Enhance Revenue Growth, Working Paper.

Myers, S. C. (1977). Determinants of Corporate Borrowing. Journal of Financial Economics, 5, 147-175. http://dx.doi.org/10.1016/0304-405X(77)90015-0

Ohlson, J. (1995, Spring). Earnings, Book Values, and Dividends in Equity Valuation. Contemporary Accounting Research, 11, 661-687. http://dx.doi.org/10.1111/j.1911-3846.1995.tb00461.x

Paek, W. S., \& Jeon, S. I. (2004). Accounting Methods for Intangible Expenditures, Persistence of Abnormal Earnings and Equity Valuation. The Accounting Review, 29(3), 199-226. [Printed in Korean]

Park, G. L. (2005). Comparison of Correlations in the Effects of Advertising Expenses after Asian Financial Crisis. Business Education Review, 38, 331-353. [Printed in Korean]

Peles, Y. (1971, October). Rates of Amortization of Advertising Expenditures. Journal of Political Economy, 79, 1032-1058. http://dx.doi.org/10.1086/259813

Picconi, M. J. (1977, Autumn). A Reconsideration of the Recognition of Advertising Assets on Financial Statements. Journal of Accounting Research, 15, 317-326. http://dx.doi.org/10.2307/2490357

Ryan, S. G. (2008). Accounting in and for the Subprime Crisis. The Accounting Review, 83(6), 1605-1638. http://dx.doi.org/10.2308/accr.2008.83.6.1605

Sen, S., \& Bhattacharya, C. B. (2001). Does Doing Good Always Lead to Doing Better? Consumer Reactions to Corporate Social Responsibility. Journal of Marketing Research, 38(2), 225-243. http://dx.doi.org/10.1509/jmkr.38.2.225.18838

Shin, M. S., Kim, S. E., \& Kim, B. S. (2011). The Effects of Corporate Social Responsibility Expenditure on Firm Value. Journal of Financial Engineering, 10(1), 99-125. [Printed in Korean]

Sougiannis, T. (1994). The Accounting Valuation of Corporate R \& D. The Accounting Review, 69, 44-68.

Swanson, E., Rees, L., \& Jaurez-Valdes, L. (2003). The Contribution of Fundamental Analysis after a Currency Devaluation. The Accounting Review, 78(3), 875-902. http://dx.doi.org/10.2308/accr.2003.78.3.875

Waddock, S. A., \& Graves, S. B. (1997). The Corporate Social Performance-Financial Performance Link. $\begin{array}{llrl}\text { Strategic Management } & \text { Journal, } & \text { 383-319. }\end{array}$ http://dx.doi.org/10.1002/(SICI)1097-0266(199704)18:4<303::AID-SMJ869>3.0.CO;2-G

White, J. B., \& Miles, M. P. (1996). The Financial Implications of Advertising as an Investment. Journal of Advertising Research, 36(4), 43-52.

Yook, K. H. (2003). A Further Examination on the Economic Impacts of Advertising and R \& D Expenditures. Journal of Business Research, 18(3), 219-251. [Printed in Korean]

Yu, H. K., \& Kim, S. J. (2006). A Study on the Determinating Factors of Corporate Contributions in Hotel Industry. Journal of Tourism Sciences, 30(5), 361-376. [Printed in Korean] 